\title{
The Role and Importance of Spa and Wellness Tourism in Hungary's Tourism Industry
}

\section{János Csapó 1 / Gergely Marton²}

e-mail: jcsapo@ukf.sk, martongergely@gamma.ttk.pte.hu

1 Department of Tourism, Faculty of Central European Studies, Constantine the Philosopher University in Nitra, Nitra, Slovak Republic

${ }^{2}$ Department of Sports Theory and Management, Institute of Sport Sciences and Physical Education, Faculty of Sciences, University of Pécs, Pécs, Hungary

Csapó, J., \& Marton, G. (2017). The Role and Importance of Spa and Wellness Tourism in Hungary's Tourism Industry. Czech Journal of Tourism, 6(1), 55-68. DOI: 10.1515/cjot-2017-0003.

\begin{abstract}
This paper presents and highlights the role and importance of spa and wellness tourism in Hungary. Ever since tourism has played an important role in the social-economic processes of the country the leading tourism product proved to be health tourism (spa and wellness) thanks to the advantageous physical geographical and socialpolitical background. After the presentation of the country-specific theoretical system of spa and wellness, the paper examines the supply and the demand side together with competitor analysis and recent trends in spa and wellness in Hungary.
\end{abstract}

\section{Keywords}

Hungary, spa and wellness, geographical conditions, supply and demand, competitors

JEL classification: $\mathrm{L} 83, \mathrm{Z} 32$ 


\section{Introduction}

This research paper intends to present and highlight the role and importance of spa and wellness tourism in Hungary. Since tourism comprises $9.8 \%$ of the total GDP and $12 \%$ of employment (both direct and indirect contribution), one can state that its role in the country's economy is inevitable (Central Statistical Office of Hungary [CSO], 2016). Since mass tourism appeared in Hungary already in the 1960s, spa and wellness proved to be the most important tourism product of the country. It is also important to stress that tourism processes of Hungary are heavily concentrated as far as time and space are concerned; the majority of the tourists visit the country from June to August and mainly visit Budapest, the capital, and Lake Balaton (Aubert, Jónás-Berki, Papp, \& Pálfi, 2015). Therefore, seasonality is one of the major structural problems of Hungary's tourism processes where such a tourism product as spa and wellness plays an outstanding role in attracting visitors for a longer period of time and extend the season.

Hungary has an outstanding potential for spa and wellness, even on international scale (Bender, Bálint, Prohászka, Géher, \& Tefner, 2014; Buzsik, Jónás-Berki, Köbli, \& Pálfi, 2015; Bakucz, Köbli, \& Hajnal, 2016). This tourism product can practically be established almost in the whole country - apart from the mountainous and hilly areas - providing a really high quality natural resource for Hungary. Based on this phenomenon, wellness and medical tourism are one of the most important factors and priority for the tourism industry of Hungary and especially for its tourism development in the past, as well as in the future.

This is basically thanks to the geological foundations related to the relative thinness of the tectonic plates underneath the Carpathian Basin (24-26 kilometres) and the high geothermic gradient resulting from this $\left(5^{\circ} \mathrm{C} / 100 \mathrm{~m}\right.$, one and a half times more than the world's average) (VITUKI, 2005). The thermal water can be found beneath roughly $80 \%$ of the country, making Hungary the 5 th most important thermal water destination after Japan, Iceland, Italy and France (Ács \& Laczkó, 2008b; Aquaprofit Múszaki, Tanácsadási és Befektetési Rt., 2007). The main focus of health tourism in Hungary is based on services built on the thermal and medicinal water, however, the other classic forms of health tourism supply (such as healthy climate, medical caves, medicinal mud or mofetta) should also be emphasized.

This paper intends to give a comprehensive survey of the importance, development and role of spa and wellness in Hungary by providing an insight into the physical geographical backgrounds, the major supply factors, the geographical allocation of spa and wellness tourism and also the demand side of this strategic tourism product.

\section{Theoretical basis}

Alongside the changes in travel patterns over the past few years, the new trends indicated the strengthening of the spa and medical tourism product (Lew, 2011; Connell, 2013; Ramírez, 2007; Hall, 2011). The overall market positions of both wellness and medical tourism has been influenced by the demographic changes (especially in the developed 
Figure 1 The system and types of health tourism in Hungary

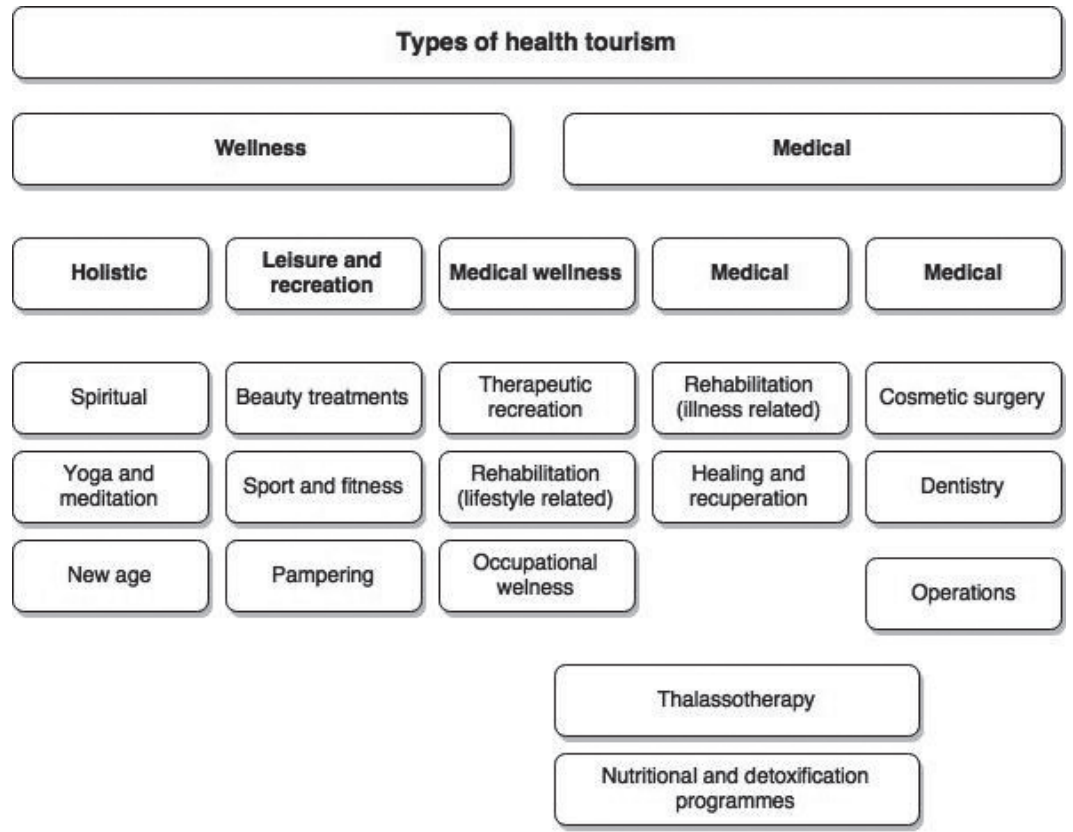

Source: Smith and Puczkó (2009)

countries) of the last decades, increase in the discretionary income, growing need for recreation and regeneration or simply by financial reasons (Horowitz, Rosensweig, \& Jones, 2007; Lunt \& Carrera, 2010).

From the beginning of the 1990s alongside the forms of classic medical and thermal tourism, a growing need for new health tourism services appeared, both globally and in Hungary, such as the different forms of wellness and fitness and the holistic approaches to preserve health (beauty treatments, diets, cleansing, Thalasso therapy, or kinetic therapy) (Kiss \& Török, 2001; Turner, 2010).

The most typical new trends based on the above described activities and services are the development of the spa culture and the further diversification of the spa and wellness tourism products (Michalkó, Rátz, Tóth, \& Kincses, 2009; Michalkó, Rátz, \& Hinek, 2012). In the opinion of the authors, the key wellness and medical tourism trends of the recent years include the growing awareness of health and healthy lifestyle, the intensive innovation of tourism products (treatments and services), the design keeping pace with fashion and the changes in customer behaviour (lifestyle) (Jónás-Berki, Csapó, Pálfi, \& Aubert, 2015).

In Hungary, both the academic world and the governing bodies denominate spa and wellness tourism as an umbrella concept for health tourism (Lengyel, 2004; Michalkó \& 
Rátz, 2010). This tourism product and at the same time, concept is very complex according to the most widely accepted definition in Hungary: "Health tourism as a comprehensive concept for medical and wellness tourism constitutes such a branch of tourism where the tourist's major motivation is to improve and/or maintain his or her state of health, in other words convalescence and/or prevention, and according to this, during the stay at the destination, health tourism service or services are requisitioned" (Aquaprofit Műszaki, Tanácsadási és Befektetési Rt., 2007, p 9.).

According to this approach, Hungarian scholars distinguish two subsectors within health tourism, specifically medical tourism and wellness tourism. However, according to the trends of the recent years, medical wellness has created a pillar for this system (Figure 1). Agreeing with Smith and Puczkó (2009), Figure 1 represents the system and types of health tourism in Hungary.

\section{Methodology}

The aim of this paper is to present and evaluate the place and role of spa and wellness in the tourism industry of Hungary. Our hypothesis is that health tourism (as this concept is used in Hungary for spa and wellness) is the leading and strategic tourism product of the country thanks to the advantageous physical geographical characteristics and also to its positive impacts on seasonality.

The authors of this paper basically used secondary data sources of the Central Statistical Office of Hungary, as well as part of the desk research including the relevant comprehensive research papers of Hungarian tourism experts and professionals.

\section{Results and Discussion}

\section{The physical geographical background and overall position of spa and wellness tourism in Hungary}

The attractions and capabilities of health tourism in Hungary are outstanding in a worldwide perspective: the allocation of the Carpathian Basin, the high values of the geothermic gradient and the quality of the host rock all contribute to its outstanding position (Aubert \& Csapó, 2004; Aubert, Jónás-Berki, \& Marton, 2012; Gonda, 2016; Michalkó \& Rátz, 2010). As a consequence of the mentioned physical geographical factors, one can find nearly 1,300 thermal springs in Hungary, out of which the qualified medical waters account for 147 (Ács \& Laczkó, 2008a, b). They are used by 56 medical hotels and 77 qualified medical spas (CSO, 2016). Thanks to this phenomenon, the number of settlements with spas is prominently high (Figure 2 ). 


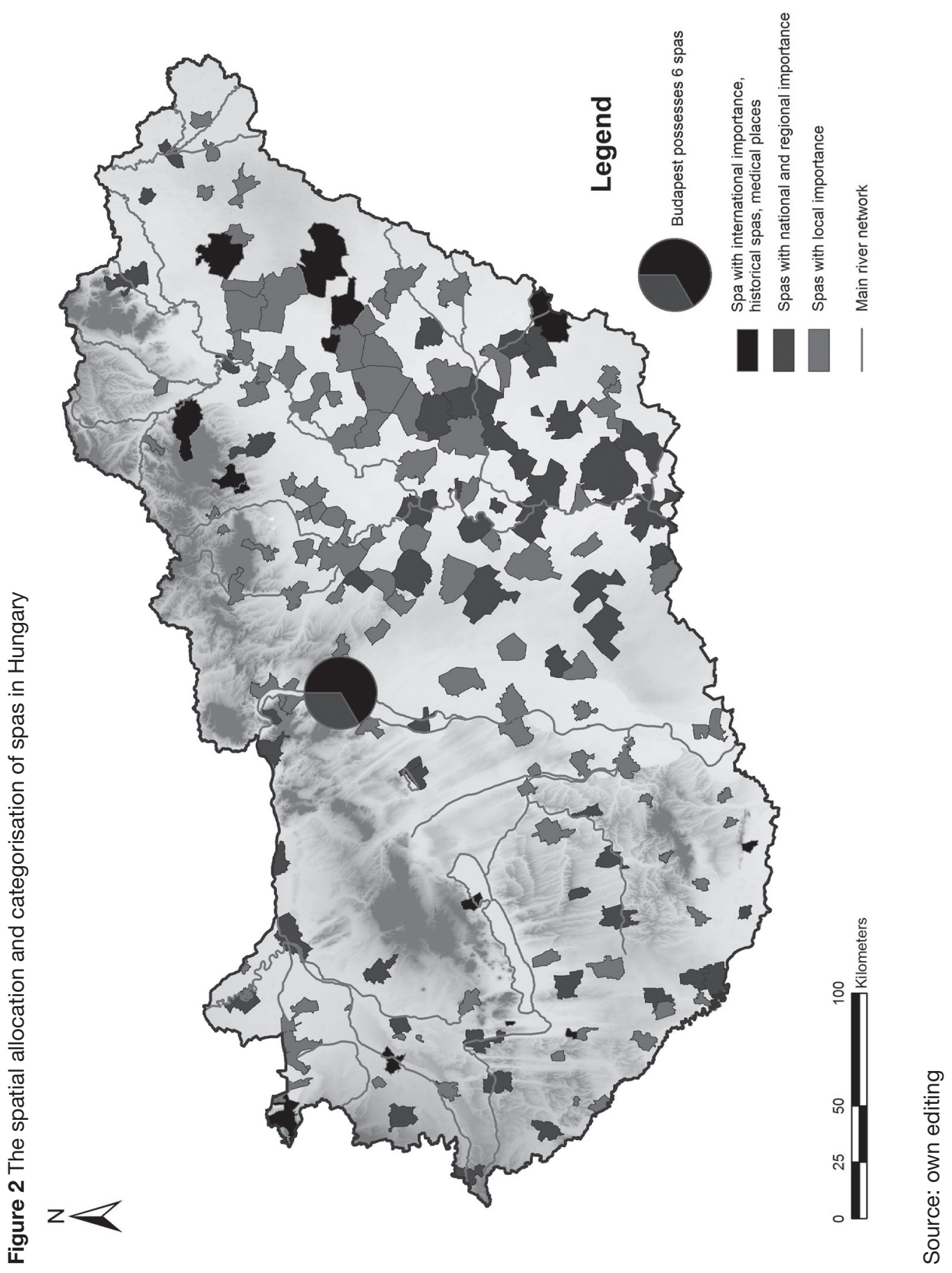


Overall, 137 settlements are involved in medical tourism, out of which 14 is qualified as medical places: Balatonfüred, Bük, Debrecen, Eger, Gyöngyös (Kékestető), Gyula, Hajdúszoboszló, Harkány, Hévíz, Miskolc (Lillafüred), Parád, Sárvár, Sopron (Balf) and Zalakaros. Nearly half of the country's population live in these resorts, which are related to medical tourism and $61 \%$ of all the bed establishments of commercial accommodation are located in these resorts (Hungarian Tourism Agency, 2017).

Based on the physical geographical endowments, four types of medical factors can be differentiated in the Hungarian spa and wellness tourism:

- Medical waters;

- Medical mud;

- Climate therapy and medical caves;

- Mofetta.

These four types of medical factors serve as the primary attractions for the following supply factors and establishments in Hungary (Table 1).

Table 1 The values/attractions built on the natural medical factors in Hungary (2016)

\begin{tabular}{|l|c|l|}
\hline $\begin{array}{l}\text { Name of the natural } \\
\text { value/attraction }\end{array}$ & $\begin{array}{l}\text { Number of the natural } \\
\text { values/attraction }\end{array}$ & \multicolumn{1}{|c|}{ Settlement (if applicable) } \\
\hline thermal springs & 1,289 & \\
\hline qualified medical site & 17 & $\begin{array}{l}\text { Hévíz, Bükfürdő, Sárvár, Balf, Zalakaros, } \\
\text { Harkány, Balatonfüred, Parád, Lillafüred, } \\
\text { Kékestető, Eger, Mezőkövesd, Debrecen, } \\
\text { Hajdúszoboszló, Gyula, Nyíregyháza-Sóstó- } \\
\text { gyógyfürdő, Szigetvár }\end{array}$ \\
\hline certified spa hotel & 36 & $\begin{array}{l}\text { Abaliget, Lilafüred, Budapest, Tapolca, } \\
\text { Jósvafő }\end{array}$ \\
\hline certified medical spa & 83 & $\begin{array}{l}\text { Makó, Tiszasüly - Kolop, Hajdúszoboszló, } \\
\text { Alsópáhok, Hévíz }\end{array}$ \\
\hline medical cave & 5 & Mátraderecske, Parádfürdő \\
\hline mineral water & 224 &
\end{tabular}

Source: Hungarian Tourism Agency (2016)

It is also worth mentioning that when the health tourism product is analysed, according to Ács and Laczkó (2008a), health tourism disposes numerous advantages compared to other branches or sectors of tourism which, of course, will play an important role in the tourism industry: 
- The negative effect of seasonality prevails;

- The average length of stay is in general longer, taking into consideration medical tourism;

- The capacity utilisation of commercial and private accommodation is better or higher;

- The tourism expenditure and the receipts are 30-35\% higher in medical tourism than in other areas or products of tourism.

\section{History and development of spa and wellness tourism in Hungary}

From the point of view of development, the Hungarian health tourism - and within that more exactly the spa culture - possesses rich historical traditions: among others, Aquincum (in today's Budapest) and some other ancient spas can be highlighted from the Roman Ages, also the spas established during the Turkish occupation or the spa developments in the 19th century, which mainly focused on the spas of Buda at that time.

During the socialist era, numerous developments and investments were carried out, not considering now their rational or irrational basis, which decisively founded the country's present health tourism basis. It is also worth mentioning that the majority of these spas still function.

After the change of the regime, the development of health tourism became a priority only after the Millennium. From 1989/1990, for almost a decade, the tourism product and its development was quite neglected and this era can be characterised by the fact that health tourism was defined only from a peripheral point of view (Csapó, Aubert, \& Marton, 2011).

The development strategies and investments which were carried out first with national support and later on with European Union funds can be classified into four major periods.

The first Széchenyi Plan, carried out from 2001-2003, supported 71 investments with 36 billion HUF, 120 million euros. This support contained development only from the national budget. The most important factor for the development was the regional development perspectives of the investments. The quantitative and qualitative development of health tourism which played a defining role in the structure of tourism of the country today, has been most apparent since the beginning of the 2000s as a result of the Hungarian development project funding (Széchenyi Plan 2000-2003) (Aubert, 2003).

Thanks to the development and investments of the last decades, the Hungarian tourism market has also been significantly restructured. With Hungary joining the European Union in 2004, new funds have become available for tourism, within the framework of the European regional policy. The investments that have taken place have fundamentally restructured the Hungarian tourism market, including the supply and the destinations of health tourism. Within the framework of the 1st National Development Plan (20042006) the investments were carried out with the EU support, but this time, the approach for the development has changed because the earlier sectoral and product centred de- 
velopment was taken over by the spatially oriented one. Within the framework of the developments - among others - the monument spas of Budapest have been renewed (Aubert \& Csapó, 2006).

Following this period, the health tourism development was connected with the New Hungary Development Plan (NDP II), which was also supported by the EU sources and concentrated on spatially oriented principles. While the 1st National Development Plan attracted less capital into the sector (mainly focusing on spa refurbishment in Budapest), the New Széchenyi Plan launched for 2007-2013 resulted in more capital involvement. Within the framework of the Széchenyi Plan and the present Széchenyi 2020 programme, the emphasis was originally on the spa development and later on the support for enhancing the visitor capacity was provided. Amongst the analysed accentuated destinations in the country, one can find locations where this latter (accommodation capacity) development has not been or only partially undertaken, leading to stagnation or even continuous decline (such as the case of Harkány, where the former Yugoslavian civil war, being allocated very near to the Hungarian-Croatian border, also caused decades' long stagnation).

The effects of the mentioned health tourism development differ both from the economic or tourism perspective. Numerous new spas were established, the sector was modernised, the commercial and private accommodation were also established, but on the other hand, in many cases, as a result of the not so adequate planning process or the abrupt market processes, there were numerous negative characteristics. These include, for example, the contention with the guests within the spa resorts in a small geographical proximity, or the local governments often became bankrupt due to the "over-investments" or the frequent change of the owners (Csapó, Aubert, \& Marton, 2011).

Based on this chapter, one can clearly state that spa and wellness tourism has been in the focus of tourism policy ever since the later period of the socialist era, but with a greater emphasis since the change of the regime. The first comprehensive health tourism development plan was published in 2007, entitled the National Health Tourism Development Strategy 2007-2013, providing the theoretical and professional background and basis for the health tourism development policy. The Hungarian government has recently accentuated the role of spa, wellness and medical tourism in the latest national tourism development strategy (Hungarian Tourism Agency, 2017).

\section{The supply and demand side of spa and wellness in Hungary}

According to the most recent data of the Central Statistical Office of Hungary, the number of thermal, medical and experience spas or aquaparks in Hungary is 224 (established in 155 resorts), while together with the swimming pools and lidos, this number accounts for 386, which is again a prominent value even from the international perspective (Table 2 ). 
Table 2 Total data of medical or thermal spas in Hungary

\begin{tabular}{|l|c|c|c|c|}
\hline \multicolumn{2}{|l|}{ Settlements with medical or thermal spas } \\
\hline Number & Area, $\mathbf{1 0 0 0} \mathbf{~ m}^{\mathbf{2}}$ & Number of pools & $\begin{array}{c}\text { Area of the pools, } \\
\mathbf{m}^{\mathbf{2}}\end{array}$ & $\begin{array}{c}\text { The greatest } \\
\text { allowed load, } \\
\text { person }\end{array}$ \\
\hline 224 & $6,332,6$ & 1,763 & 401,876 & 202,967 \\
\hline
\end{tabular}

Source: CSO (2015)

Figure 3 The regional allocation and share of different kinds of spas in Hungary (2016)

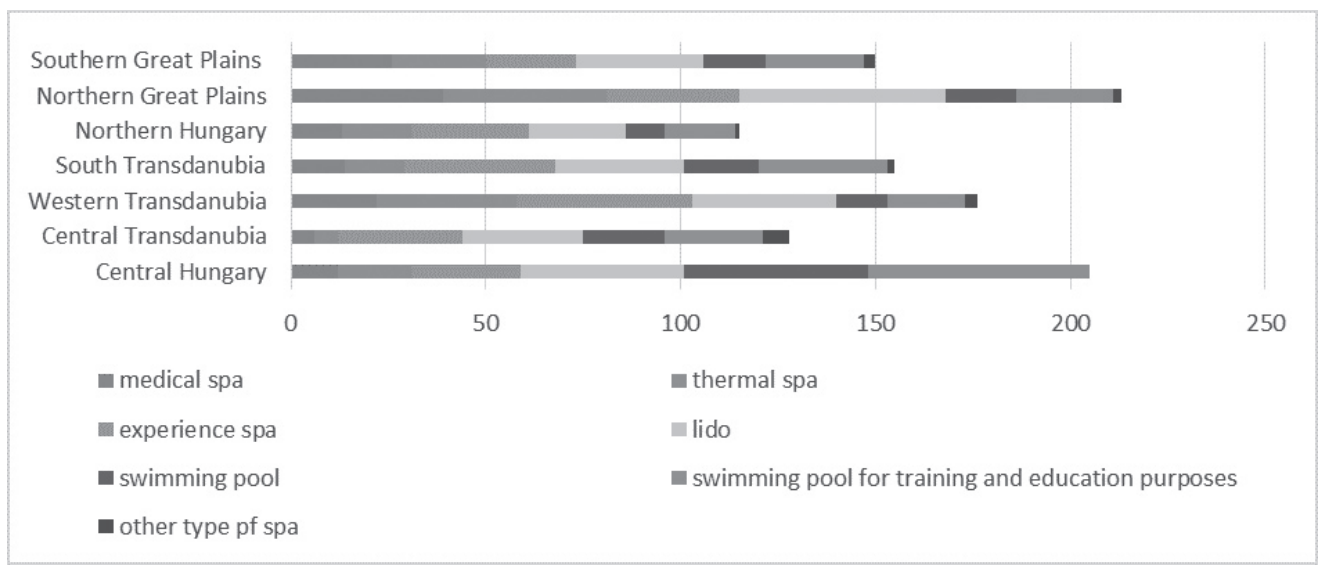

Source: Based on CSO data (2016), own editing

Based on their services, quality, size and attractiveness - according to their importance - the spas can be classified into international, national/regional and local categories (Hungarian Spa Association, 2010) According to this approach, the National Health Tourism Development Strategy distinguishes 17 spas and medical sites with international importance, 60 with national importance and 110 with local importance.

Considering the regional allocation of the different kinds of spas (Figure 3), one can assume that the greatest density can be found in the Northern Great Plains and in Central Hungary, but Western Transdanubia possesses excellent conditions in this respect as well, which is again determined by - but not only - the physical geographical background of the country.

It should be also highlighted that in order to provide the best quality possible, the Hungarian Spa Association (Magyar Fürdőszövetség) developed an official qualification method where the spas (experience spa, wellness spa, medical spa, swimming pool or 
lido) are qualified on the basis of a 1-5 scale list (stars) and achieve the official trademark. So far, 21 spas have received the National Evidentiary Trademark for Spas.

The volume of health tourism can primarily be measured in spas and in commercial accommodation specialised in wellness or medical tourism. Visitor numbers to Hungarian spas generate more than 40 million visits per year, out of which the thermal and medical spas register around 23 and 24.5 million visitors per year (CSO, 2016; Jónás-Berki, Csapó, Pálfi, \& Aubert, 2015; Hungarian Spa Association, 2010).

It is also characteristic of the Hungarian tourism industry, at the same time, representing the importance of health tourism, that the top 10 visited resorts of the past years have been mostly spa towns (usually 7 or 8) (Hungarian Tourism Agency, 2016). The 155 settlements having thermal or medical spas possess 205,973 beds in commercial establishments, out of which almost $50 \%$ can be found in hotels and 87,944 beds in other types of establishments (former private accommodation) where altogether 8,210,696 guests were registered with an average stay of 2.6 nights (CSO, 2016).

According to those establishments where the major motivation is wellness or medical reasons, the Central Statistical Office publishes data only about the latter ones (from 2013 one can find no official data about the wellness hotels in Hungary). According to this, the purely medical hotels accommodated $6.4 \%$ of all the guests in Hungary, with $8.61 \%$ of all the hotels' guest nights in 2016 (CSO, 2017). One can, however, find some information on the websites offering accommodation with wellness focus and therefore, one can estimate that around 750 establishments provide such services for their guests in the country.

2016 was an outstanding year for Hungary's tourism and also for medical tourism since the number of guests grew by $6.8 \%$ and the guest nights by $6.1 \%$ compared to 2015 . The ratio of international and domestic guests was 58.6-49.1 and the average stay of the guests was 3.3 nights (international guests 4.1 nights, domestic guests 2.8 nights,) which is unfortunately a relatively low data, especially compared to the international examples. The most important countries for Hungarian health tourism demand are Germany (21.1 $\%)$, Austria (11\%), the Czech Republic (9.7\%) and Slovakia (4.8\%). (Hungarian Tourism Agency, 2017) According to the latest official statistics, $12.9 \%$ of all the international visitors are coming to Hungary because of spa and wellness (CSO, 2017).

The domestic demand is also strengthened with the incentive of the Széchenyi Card, a state supported tool to enhance the domestic tourists choice to stay in Hungary for recreational purposes.

Based on the above mentioned and the major directions of tourism product development of the country, the functional-spatial typology of spa and wellness tourism centres can also be characterised (Jónás-Berki, Csapó, Pálfi, \& Aubert, 2015). As it has been stated earlier (Jónás-Berki, Csapó, Pálfi, \& Aubert, 2015), the emergence and characteristics of health tourism destinations are influenced primarily by the existence of the key feature, the attraction, although by now health tourism based on medical services represents an equally important role as health tourism based on medicinal features. Health tourism in Hungary generally builds upon natural medicinal features (Michalkó \& Rátz, 2010, 2011), such as medicinal water, medicinal caves, medicinal mud and special micro- 
climate. On the contrary to this, wellness tourism destinations base their offer on services and further product features influence their development (e.g., potential demand, accessibility or competition). Looking at the product structure of wellness destinations, it can be concluded that the medical services have growing importance, therefore, these destinations are also aware of the added value of healthcare provided.

Due to the complexity of health tourism or spa and wellness in Hungary, one can differentiate different types or categories of supply, such as special medical tourism centres (e.g., Balf), as well as medical centre with wellness profile (e.g., Bük, Sárvár, Hévíz, Harkány), places where medical and wellness services are present equally (e.g., Hajdúszoboszló), and wellness tourism centres (the day spas) (Aubert, Jónás-Berki, \& Marton, 2012).

\section{Competitors}

Despite the excellent potential, Hungary has to face a growing competition on the international health tourism market. Therefore, the assessment of the competitors is a key task of tourism development (Michalkó, Rátz, \& Hinek, 2012; Rátz \& Michalkó, 2011). In the global content, every country or destination can be regarded as a competitor possessing a health tourism supply of partially or completely international importance. The direct competitors of Hungary are European countries with special attention to its neighbours, specifically, Austria, Slovenia, Slovakia and Romania offering spas of national and international importance and/or other health tourism services, which have undergone significant improvements in the last decade (Lew, Hall, \& Timothy, 2008).

Although with a different supply structure, alongside the neighbouring countries, the Czech Republic and Italy have outstanding thermal and medical tourism propositions with international importance on the tourism market. Wellness tourism, the other pillar of health tourism, shows an even more varied picture as natural resources play less significant role. Apart from Hungary's direct neighbours and the other competing destinations, Poland and Russia need to be regarded as serious competitors in terms of existing and future wellness tourism potential (Lew, Hall, \& Timothy, 2008).

\section{Conclusion}

The present paper intended to provide a general insight into the role and importance of spa and wellness as a tourism product in Hungary. Health tourism has become one of the most important strategic tourism products of the country, primarily based on the advantageous physical geographical features.

Hungary possesses rich heritage not just with respect to its geological establishments, but also to its complete range of the tourism supply of spa and wellness. This supply, the infrastructural development, was also promoted by different governments and state actors from the socialist era from the 1960s when the state first realised the importance of tourism. However, in the recent decades, especially since the 2000s, the spa develo- 
pment and the relative geographical distance (or proximity) of these investments have challenged the competitiveness of all the spas and their sustainability (Csapó, Aubert, \& Marton, 2011).

Based on the supply side, due to the new trends of tourism, a considerable amount of demand has appeared as well in the spa and wellness sector of Hungary, both from the domestic and the international market. Furthermore, the domestic demand is strongly promoted by the state supported incentives, such as the so-called Széchenyi Card. The majority of the international guests visit Hungary from the neighbouring countries, but Germany, Italy, the Czech Republic or Poland also plays an important role.

Finally, it has to be stressed that there is a strong spatial concentration of the spa and wellness demand in the country, relying on the supply of Budapest, Lake Balaton and the western areas of Hungary. However, the seasonality is much lower in this tourism segment, compared to the general situation in Hungary, and visitors spend more time and more money on spa and wellness than on any other tourism product in the country.

\section{References}

Ács P., \& Laczkó T. (2008b). Spatial Concentration of Hungary's Health Tourism. Modern Geográfia , 3(2), 1-22.

Ács, P., \& Laczkó, T. (2008a). Területi különbségek a hazai egészségturizmus kínálatában. Területi Statisztika, 3, 344-356.

Aquaprofit Műszaki, Tanácsadási és Befektetési Rt. (2007). Országos Egészségturizmus Fejlesztési Stratégia (National Health Tourism Development Strategy). Budapest: Önkormányzati és Területfejlesztési Minisztérium (Ministry of Local Government and Regional Development). Retrieved May 12, 2013 from http://www.kormany.hu/download/b/8e/20000/Egeszsegturizmusstrategia.pdf.

Aubert, A., \& Csapó, J. (2004). Egészségturizmus. Pécs, Hungary: Bornus Nyomda.

Aubert, A., \& Csapó, J. (2006). Planning and Development Aspects of Tourism in the Regional and Rural Development Programs in Hungary. In J. Ježek (ed.), New Members - New Challenges for the European Regional Development Policy (pp. 1-9). Bratislava, Slovak Republic: University of Economics in Bratislava.

Aubert, A. (2003). Tourismus in Ungarn: Struktur-Dynamik-Perspektiven. In C. Becker, H. Hopfinger \& A. Steinecke (eds.), Geographie der Freizeit und des Tourismus: Bilanz und Ausblick (pp. 582-591). München/Wien: Oldenbourg Verlag.

Aubert, A., Jónás-Berki, M., \& Marton, G. (2012). Spatial Organisation and Management Characteristics of Health Tourism in Hungary. Central European Regional Policy and Human Geography, 2(2), 27-36.

Aubert, A., Jónás-Berki, M., Papp, J., \& Pálfi, A. (2015). Regional processes and spatial disparities of tourism in the period 2004-2014. In J. Maier (ed.), Sozialer und wirschaftlicher Strukturwandel in Mitteleuropa 2004-2014 (pp. 155-168). Bayreuth, Germany: Universität Bayreuth.

Bakucz, M., Köbli, Á., \& Hajnal, K. (2016). A gyógy- és termálturizmus versenyképessége néhány közép-európai régióban. Földrajzi Közlemények, 140(4), 376-393. 
Bender, T., Bálint, G., Prohászka, Z., Géher, P., \& Tefner, I. K. (2014). Evidence-based hydro- and balneotherapy in Hungary-a systematic review and meta-analysis. International Journal of Biometeorology, 58(3), 311-323. DOI: 10.1007/s00484-013-0667-6.

Buzsik, K., Jónás-Berki, M., Köbli, Á., \& Pálfi, A. (2015). Actual Trends of Health Tourism In Hungary: The Case of Hévíz. Geographica Timisiensis, 24(2), 45-53.

Central Statistical Office of Hungary [CSO]. (2015). Turizmus, vendéglátás. Retrieved from https:// www.ksh.hu/turizmus_vendeglatas.

Central Statistical Office of Hungary [CSO]. (2016). Turizmus, vendéglátás. Retrieved from https:// www.ksh.hu/turizmus_vendeglatas.

Central Statistical Office of Hungary [CSO]. (2017). Turizmus, vendéglátás. Retrieved from https:/ / www.ksh.hu/turizmus_vendeglatas.

Connell, J. (2013). Contemporary medical tourism: Conceptualisation, culture and commodification. Tourism Management, 34(February), 1-13. DOI: 10.1016/j.tourman.2012.05.009.

Csapó, J., Aubert, A., \& Marton, G. (2011). The Role of Health Tourism in the Hungarian Small and Medium Sized Towns. In J. Ježek \& L. Kaňka (eds.), Competitiveness and Sustainable Development of the small Towns and Rural Regions in Europe (pp. 29-40). Plzen, Czech Republic: University of West Bohemia.

Gonda, T. (2016). A turisztikai termékfejlesztés elméleti alapjai. Szekszárd, Hungary: PTE, Kultúratudományi, Pedagógusképző és Vidékfejlesztési Kar.

Hall, C. M. (2011). Health and medical tourism: a kill or cure for global public health?. Tourism Review, 66(1/2), 4-15. DOI: 10.1108/16605371111127198.

Horowitz, M. D., Rosensweig, J. A., \& Jones, C. A. (2007). Medical Tourism: Globalization of the Healthcare Marketplace. Medscape General Medicine, 9(4), 33.

Hungarian Spa Association. (2010). A Magyar Fürdöszövetség helyzetértékelése és javaslatai a magyar egészségturizmus versenyképességének javitása érdekében. Budapest, Hungary: Magyar Fürdőszövetség. Retrieved from http://www.aktivpihenes.hu/fooldal/a_magyar_fuerdoeszoevetseg_helyzetertekeles_az_egeszsegturizmus.

Hungarian Tourism Agency. (2016). Database. Retrieved from www.itthon.hu.

Hungarian Tourism Agency. (2017). Magyarország turizmusának alakulása 2016-ban az elózetes adatok szerint. Budapest, Hungary: Magyar Turisztikai Ügynökség. Retrieved from http://szakmai.itthon.hu/documents/28123/4083489/Magyarorszag_turizmusa_2016_elozetes_adatokkal.pdf/ e5a00164-bba2-40a7-a698-6847ea84d5de.

Hungarian Tourism Agency. (2017). National Tourism Development Strategy 2030 (Nemzeti Turizmusfejlesztési Stratégia 2030). Budapest, Hungary: Magyar Turisztikai Ügynökség. Retrieved from http://szakmai.itthon.hu/documents/28123/44398839/mtu_strategia_2030.pdf/7050387a5c65-4738-86f8-f898a752fdb0.

Jónás-Berki, M., Csapó, J., Pálfi, A., \& Aubert, A. (2015). A Market and Spatial Perspective of Health Tourism Destinations: The Hungarian Experience. International Journal of Tourism Research, 17(6), 602-612. DOI: 10.1002/jtr.2027.

Kiss, K., \& Török, P. (2001). Az egészségturizmus nemzetközi keresleti és kínálati trendjei. Turizmus Bulletin, 5(3), 7-14.

Lengyel, M. (2004). A turizmus általános elmélete. Budapest, Hungary: KIT-HFF.

Lew, A. A. (2011). Tourism's Role in the Global Economy. Tourism Geographies an International Journal of Tourism Space, Place and Environment, 13(1), 148-151.

Lew, A., Hall, C. M., \& Timothy, D. J. (2008). World geography of travel and tourism: a regional approach. Oxford, UK: Elsevier. 
Lunt, N., \& Carrera, P. (2010). Medical tourism: Assessing the evidence on treatment abroad. $M a$ turitas, 66(1), 27-32. DOI: 10.1016/j.maturitas.2010.01.017.

Michalkó, G., \& Rátz, T. (2010). Hungarian Spa Destinations in the Tourism-oriented Property Market, Hungarian Geographical Bulletin, 59(2), 131-146.

Michalkó, G., \& Rátz, T. (2011). Egészségturizmus és életminöség Magyarországon: Fejezetek az egészség, az utazás és a jól(l)ét magyarországi összefüggéseiról. Budapest, Hungary: MTA FKI.

Michalkó, G., Rátz, T., \& Hinek, M. (2012). Spatial Differences in Hungarian Medical Tourism Supply Based on Service Providers' Online Presence. Hungarian Geographical Bulletin, 61(1), 31-47.

Michalkó, G., Rátz, T., Tóth, G., \& Kincses, Á. (2009). A gyógyfürdővel rendelkező magyarországi települesek életminőségének vizsgálata. Területi Statisztika, 2, 170-186.

Országos Gyógyhelyi és Gyógyfürdóügyi Fóigazgatóság (OGYFI) (National Medical Site and Medical Spa Directorate). Retrieved from http:/ / efrira1.antsz.hu/portal/page?_pageid=240,47301\&_da$\mathrm{d}=$ portal\&_schema $=$ PORTAL.

Ramírez de Arellano, A. B. (2007). Patients Without Borders: The Emergence of Medical Tourism. International Journal of Health Services, 37(1), 193-198.

Rátz, T., \& Michalkó, G. (2011). The contribution of tourism to well-being and welfare: the case of Hungary. International Journal of Sustainable Development, 14(3/4), 332-346. DOI: 10.1504/ IJSD.2011.041968.

Smith, M., \& Puczkó, L. (2009). Health and wellness tourism. Oxford, UK/Burlington/MA: Butterworth-Heinemann.

Turner, L. (2010). "Medical Tourism" and the Global Marketplace in Health Services: U.S. Patients, International Hospitals, and the Search for Affordable Health Care. International Journal of Health Services, 40(3), 443-467. DOI: 10.2190/HS.40.3.d.

VITUKI. (2005). A fürdöfejlesztésekkel kapcsolatban a hazai termálvizkészlet fenntartható hasznosításáról és a használt viz kezeléséról szóló hidrogeológiai kutatás (The hydrogeological research on the sustainable utilization of the domestic thermal water pool and the management of the water used for bath developments) (No. 721/1/6418-01). Budapest, Hungary: Author. Retrieved from http://www.vituki. $\mathrm{hu} /$ index.php?option=com_content\&task=view\&id=84\&Itemid=96. 